\title{
Enumerating asymptomatic COVID-19 cases and estimating SARS-CoV-2 fecal shedding rates via wastewater-based epidemiology
}

Bradley W. Schmitz ${ }^{\mathrm{a}, \uparrow}$, Gabriel K. Innes ${ }^{\mathrm{b}} \uparrow$, Sarah M. Prasek ${ }^{\mathrm{c}}$, Walter Q. Betancourt ${ }^{\mathrm{c}}$, Erika R. Stark $^{\mathrm{c}}$, Aidan R. Foster ${ }^{\mathrm{c}}$, Alison G. Abraham ${ }^{\mathrm{d}}$, Charles P. Gerba ${ }^{\mathrm{c}}$, and Ian L. Pepper ${ }^{\mathrm{c}, *}$

a Yuma Center of Excellence for Desert Agriculture (YCEDA), University of Arizona, 6425 W. $8^{\text {th }}$ St., Yuma, AZ 85364, USA

${ }^{b}$ Department of Epidemiology, School of Public Health, Rutgers University, 683 Hoes Lane West, Piscataway, New Jersey 08854, USA.

${ }^{\mathrm{c}}$ Water \& Energy Sustainable Technology (WEST) Center, University of Arizona, 2959 W. Calle Agua Nueva, Tucson, AZ 85745, USA.

${ }^{\mathrm{d}}$ Department of Epidemiology, School of Public Health, University of Colorado Anschutz Medical Campus, 1635 Aurora Ct, Aurora, CO 80045, USA.

$\dagger$ These first authors contributed equally to this article.

*Corresponding author. Bradley Schmitz. Mailing address: 6425 W. $8^{\text {th }}$ St., Yuma, AZ 85364. Tel: 480-482-0682. Email: bschmitz@arizona.edu

Running title: Enumerating SARS-CoV-2 Fecal Shedding and Asymptomatic Cases via Wastewater 
medRxiv preprint doi: https://doi.org/10.1101/2021.04.16.21255638; this version posted April 18, 2021. The copyright holder for this preprint (which was not certified by peer review) is the author/funder, who has granted medRxiv a license to display the preprint in perpetuity.

It is made available under a CC-BY-NC-ND 4.0 International license .

\section{Highlights}

- Wastewater-based epidemiology with clinical testing monitored SARS-CoV-2 in dorms.

- $79.2 \%$ of SARS-CoV-2 infections were asymptomatic, and $20.8 \%$ were symptomatic.

- Clinical and wastewater data aggregated to estimate SARS-CoV-2 fecal shedding rate.

- Mean fecal shedding rate based on the N1 gene was $6.84 \pm 0.77 \log _{10} \mathrm{gc} / \mathrm{g}$-feces.

- Mean fecal shedding rate based on the N2 gene was $7.74 \pm 0.53 \log _{10}$ gc/g-feces. 


\section{Graphical Abstract}

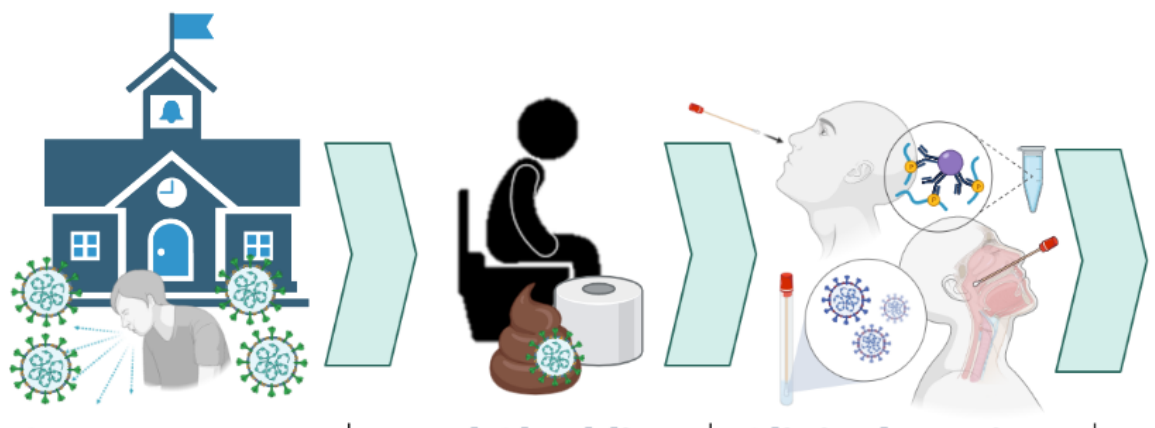

Campus Dorms | Fecal Shedding | Clinical Testing
Asymptomatic

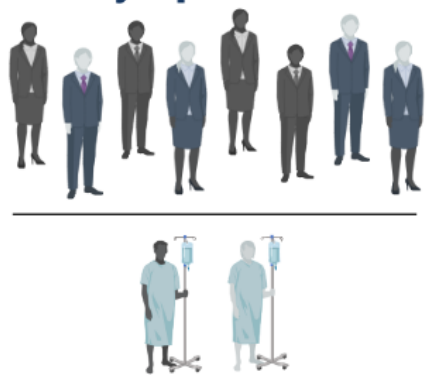

Symptomatic 
medRxiv preprint doi: https://doi.org/10.1101/2021.04.16.21255638; this version posted April 18, 2021. The copyright holder for this preprint (which was not certified by peer review) is the author/funder, who has granted medRxiv a license to display the preprint in perpetuity.

It is made available under a CC-BY-NC-ND 4.0 International license .

\section{Abstract}

Wastewater-based epidemiology (WBE) was utilized to monitor SARS-CoV-2 RNA in

3 sewage collected from manholes specific to individual student dormitories (dorms) at the

4 University of Arizona in the fall semester of 2020, which led to successful identification and

5 reduction of transmission events. Positive wastewater samples triggered clinical testing of almost

6 all residents within that dorm; thus, SARS-CoV-2 infected individuals were identified regardless

7 of symptom expression. This current study examined clinical testing data to determine the

8 abundance of asymptomatic versus symptomatic cases in these defined communities. Nasal and

9 nasopharyngeal swab samples processed via antigen and PCR tests indicated that $79.2 \%$ of

10 SARS-CoV-2 infections were asymptomatic, and only $20.8 \%$ of positive cases reported COVID-

1119 symptoms at the time of testing. Clinical data was paired with corresponding wastewater virus

12 concentrations, which enabled calculation of viral shedding rates in feces per infected person(s).

13 Mean shedding rates averaged from positive wastewater samples across all dorms were $6.84 \pm$

$140.77 \log _{10}$ genome copies per gram of feces (gc/g-feces) based on the $\mathrm{N} 1$ gene and $7.74 \pm 0.53$

$15 \log _{10} \mathrm{gc} / \mathrm{g}$-feces based on the N2 gene. Quantification of SARS-CoV-2 fecal shedding rates from

16 infected persons has been the critical missing component necessary for WBE models to measure

17 and predict SARS-CoV-2 infection prevalence in communities. The findings from this study can

18 be utilized to create models that can be used to inform public health prevention and response

19 actions.

21 Keywords: SARS-CoV-2, fecal shedding, asymptomatic, SARS-CoV-2 infection, public health

22 response, wastewater-based epidemiology, COVID-19, dormitories 
medRxiv preprint doi: https://doi.org/10.1101/2021.04.16.21255638; this version posted April 18, 2021. The copyright holder for this preprint (which was not certified by peer review) is the author/funder, who has granted medRxiv a license to display the preprint in perpetuity.

It is made available under a CC-BY-NC-ND 4.0 International license .

\section{Introduction}

SARS-CoV-2 infections may not end with current vaccination efforts. Some scientists conjecture that the virus' evolution may require long-term monitoring and more intensive public health measures to control transmission of new variants. Thus, additional public health surveillance strategies can and should be implemented to prevent and respond to outbreaks; wastewater based epidemiology (WBE) may be one of those tools.

Human wastewater (i.e., sewage) may be among the first indications of aggregated,

31 population-based SARS-CoV-2 infections in a community (Medema et al., 2020b), followed by

32 healthcare facility reported number of infections, hospitalizations, and ultimately deaths. WBE is

33 an effective, critical tool that has been demonstrated to monitor concentrations of SARS-CoV-2

34 RNA in wastewater as an indicator to survey the SARS-CoV-2 infection prevalence at a

35 population level (Medema et al., 2020b). The results from these surveys can be used to track

36 community infection dynamics (Peccia et al., 2020) and guide targeted public health response

37 actions (Betancourt et al., 2021). Therefore, fecal shedding of SARS-CoV-2 may be utilized as a

38 biomarker to estimate SARS-CoV-2 infections in a population..

39 Shedding estimates of SARS-CoV-2 from infected individuals have strong implications

40 for the effectiveness of WBE to determine disease prevalence and guide public health

41 interventions. Although SARS-CoV-2 has been shown to shed in the upper respiratory tract, the

42 lower respiratory tract, feces, urine and serum (Cevik et al., 2020), WBE leverages RNA

43 shedding of SARS-CoV-2 in feces. Infected persons shed virus into sewage via feces (Cevik et

44 al., 2020), or urine (Brönimann et al., 2020), both of which can then be used to monitor

45 population-level infection changes. Although SARS-CoV-2 has been isolated in urine of a

46 COVID-19 patient (Sun et al., 2020), the incidence of the virus in urine is reported to be low 
medRxiv preprint doi: https://doi.org/10.1101/2021.04.16.21255638; this version posted April 18, 2021. The copyright holder for this preprint (which was not certified by peer review) is the author/funder, who has granted medRxiv a license to display the preprint in perpetuity. It is made available under a CC-BY-NC-ND 4.0 International license.

47 (Brönimann et al., 2020; Morone et al., 2020); whereas, intact SARS-CoV-2 virus have been 48 isolated from feces (Wang et al., 2020; Xiao et al., 2020; Zhang et al., n.d.). Further, viral RNA

49 has been recovered even in the absence of intact virus isolation from stool samples (Wölfel et al., 50 2020), highlighting the sensitivity of molecular methods applied for WBE. During the early stages of the pandemic in the Netherlands, SARS-CoV-2 was detected in

52 sewage six days before initial cases were reported (Medema et al., 2020a). Mulitple jurisdictions

53 around the world have monitored concentrations of SARS-CoV-2 RNA in sewage samples to

54 quantify the total number of infected persons in the community that excreted the virus into

55 wastewater (Ahmed et al., 2020; Chavarria-Miró et al., 2021; Curtis et al., 2020). More recently,

56 the University of Arizona (UArizona) used WBE, dovetailed with targeted clinical testing, to

57 prevent COVID-19 outbreaks in student dormitories (dorms). In particular, 91 wastewater

58 samples containing SARS-CoV-2 RNA provided early-warning that at least one infected

59 individual was present in the community (Betancourt et al., 2021). The UArizona case study

60 highlighted the effectiveness of WBE to detect the presence of SARS-CoV-2 infected individuals

61 in a defined community and to ultimately contain outbreaks by triggering public health response

62 actions. Although WBE has been utilized to raise the alert of SARS-CoV-2 presence with a

63 dichotomous threshold, quantifying the number of SARS-CoV-2 infected individuals cannot be

64 done without accurate fecal shedding rate estimates.

This research aims to estimate SARS-CoV-2 fecal shedding rates in infected persons by

66 aggregating data from positive wastewater samples with numbers of known symptomatic and

67 asymptomatic individuals in defined communities. To that end, the Campus Re-entry study at the

68 UArizona in Fall 2020 (Betancourt et al., 2021) provided a unique setting to calculate mean

69 shedding rates for defined communities. Specifically, 13 dorms served as a case study to test the 
medRxiv preprint doi: https://doi.org/10.1101/2021.04.16.21255638; this version posted April 18, 2021. The copyright holder for this preprint (which was not certified by peer review) is the author/funder, who has granted medRxiv a license to display the preprint in perpetuity.

It is made available under a CC-BY-NC-ND 4.0 International license .

utility of WBE to monitor SARS-CoV-2 levels in sewage and initiate public health action based

71 upon those results. Positive SARS-CoV-2 detection in wastewater samples from any given dorm

72 led to point prevalence antigen and/or PCR testing for the vast majority of dormitory residents

73 regardless of symptomatic expression; thus, the numbers of symptomatic and asymptomatic

74 individuals was known. This current study determines the proportion of COVID-19 infections

75 that were asymptomatic versus symptomatic and pairs these clinical data with wastewater results

76 to extrapolate the fecal shedding rate of SARS-CoV-2 in infected students. Findings from this

77 study will inform how WBE can be utilized for public health prevention and response actions.

2. Methods

\subsection{Dormitory Sites}

In total, 13 dorms (Dorm A-M) were monitored throughout the Fall 2020 Semester

81 (August 17-November 20). Data from the final weeks of classes and exams following the

82 Thanksgiving break (November 21-December 17) are not included in this analysis, as students

83 were advised to complete the semester virtually and not return to campus. Each wastewater

84 sample was collected from sewer manholes specific to each dorm's effluent prior to convergence

85 with other sewer pipelines; thus, all wastewater samples were specific to the defined

86 communities living in each dorm. However, two sets of dorms (Dorm E and F; Dorm H and I)

87 required sampling from a single sewer manhole distal from the mixing of wastewater from the

88 two dorms but proximal to convergence with other pipelines. The dorms in each set are located

89 directly side-by-side and were considered a 'combined dorm' for all public health response

90 actions (i.e., clinical testing interventions) and data analysis. Dorms varied in infrastructure and

91 resident occupancy (Table 1). Due to the pandemic, UArizona limited dorm room occupancy to a

92 maximum of two. 
medRxiv preprint doi: https://doi.org/10.1101/2021.04.16.21255638; this version posted April 18, 2021. The copyright holder for this preprint (which was not certified by peer review) is the author/funder, who has granted medRxiv a license to display the preprint in perpetuity.

It is made available under a CC-BY-NC-ND 4.0 International license .

\subsection{Wastewater Sampling and Analysis}

Wastewater samples from each dorm were collected between 9:00 and 10:30 am, then analyzed for SARS-CoV-2 RNA at least twice per week. One set of dorms was monitored on Monday/Wednesday/Friday (Dorms A, B, C, D, G, L), while a second set was monitored Tuesday/Thursday/Saturday (Dorms E-F, H-I, J, K, M). Grab samples were collected inside sewer manholes with sterile Nalgene ${ }^{\circledR}$ bottles that were affixed to extension poles, which allowed collection at depths of 5 to 15 feet. Velocity $\left(\mathrm{ft}^{3} / \mathrm{s}\right)$ of wastewater within the sewer was measured using a Global Water FP 211 flow probe (Global Water, College Station, TX). Multiple readings of the minimum and maximum flow rates (gallons per minute) over a oneminute period were averaged and recorded. Flow rates were calculated using Manning's equation for partially full pipes (Akgiray, 2005). For all wastewater samples, the wastewater's height and depth was estimated to be approximately two inches, based upon the height of the fluid on the propellor sensor. Note, this assumption was necessary since exact measurements were not possible inside sewer manholes. The depth of the wastewater was never above the propellor sensor and a velocity reading could not be recorded if wastewater height was not near the top of the propellor (2-inch height) but was nonetheless considered reasonable. Statistical methods were used to estimate flow rates for samples for which velocity could not be measured due to site obstruction or the flow probe not being available (See Section 2.6).

Grab samples collected at the same time of each sampling day were considered adequate based on a prior multiple sampling event. In that case, multiple samples were collected at a particular site over a 30-minute period, and analysis indicated virtually identical virus concentrations (Betancourt et al., 2021). This suggest that virus particles disperse upon entering the piping/sewer and remain in the sewer for extended periods of time rather than being removed 
medRxiv preprint doi: https://doi.org/10.1101/2021.04.16.21255638; this version posted April 18, 2021. The copyright holder for this preprint (which was not certified by peer review) is the author/funder, who has granted medRxiv a license to display the preprint in perpetuity.

It is made available under a CC-BY-NC-ND 4.0 International license .

116 by plug flow (Manor et al., 2014). Samples were stored on ice and travel time to WEST was 30

117 minutes or less from the dorms. Wastewater processing and analysis for SARS-CoV-2 RNA

118 followed procedures previously described (Betancourt et al., 2021). Samples were tested for the

119 virus using the United States (U.S.) Centers for Disease Control and Prevention (CDC) RT-PCR

120 assays that target regions of the $\mathrm{nCoV}$ nucleocapsid gene (N1 and N2; Table S1) (Research use

121 only kit, Integrated DNA Technologies, Coralville, IA). Real-time PCR for the simultaneous

122 detection of N1 and N2 genes was performed on a LightCycler 480 Instrument II (Roche

123 Diagnostics) with the LightCycler ${ }^{\circledR}$ Multiplex RNA Virus Master (Roche Diagnostics) (Table

124 S2).

125 2.3. Clinical Testing Data

126 Positive detection of SARS-CoV-2 RNA (via N1 and N2 gene regions) in wastewater

127 was utilized as a leading indicator of the presence of SARS-CoV-2 infections within the dorm

128 communities. Results were immediately communicated to the UA Task Force and Campus Re-

129 Entry Working Groups, which planned and conducted clinical testing of residents as a response

130 action(s), as previously described (Betancourt et al., 2021).

131 Clinical tests for COVID-19 diagnosis were performed by antigen testing via nasal swab

132 samples and RT-PCR via nasopharyngeal swab samples (Betancourt et al., 2021). The analytical

133 performance characteristics for the antigen test were $96 \%$ sensitivity and $100 \%$ specificity, as

134 provided by the manufacturer (Sofia SARS Antigen FIA, Quidel, San Diego, CA, USA).

135 Performance of the RT-PCR tests were determined by the University of Arizona Genetics Core

136 for Clinical Services (CDC 2019-nCoV RT-PCR Diagnostic Panel) with a limit of detection at

137150 viral copies/reaction, or 30 viral copies/ $\mu 1$ of sample. 
medRxiv preprint doi: https://doi.org/10.1101/2021.04.16.21255638; this version posted April 18, 2021. The copyright holder for this preprint (which was not certified by peer review) is the author/funder, who has granted medRxiv a license to display the preprint in perpetuity.

It is made available under a CC-BY-NC-ND 4.0 International license .

142 of non-self-reporting (i.e., asymptomatic and sub-clinical) students and employees was

143 conducted through the TATS program that runs several testing locations on campus and

144 mobilizes pop-up sites as needed (i.e., targeted clinical testing at dorms with positive wastewater

145 detection of SARS-CoV-2). A negative antigen test at CHS, where patients were exhibiting

146 symptoms, was followed by PCR testing to confirm results; data was de-duplicated in situations

147 when both testing methods were used to confirm test results (Betancourt et al., 2021). To ensure

148 compliance with the Human Subjects Protection Program (HSPP), the use of clinical data was

149 reviewed and approved by a UArizona Institutional Review Board (IRB).

\subsection{Alignment of wastewater and clinical data}

To estimate the number of SARS-CoV-2 infected individuals who contributed to a single

152 positive wastewater sample, a 6-day range of clinical data was considered. Positive clinical cases

153 from the day before, day-of, and four days after sampling were included in the count of infected

154 individuals contributing to viral shedding. The rationale for this approach is:

1) Residual virus - shed from individuals testing positive for COVID-19 the day prior to

156 sampling — may be detected in wastewater the following day. Previous sampling indicates that

157 virus can persist for extended periods of time and be detected even when an estimated 1000

158 gallons of wastewater has continued to flow through a sewer system (Betancourt et al., 2021).

2) Individuals infected with SARS-CoV-2 may shed virus into wastewater prior to

160 showing symptoms and/or being identified as a clinical case. The viral load of SARS-CoV-2 
medRxiv preprint doi: https://doi.org/10.1101/2021.04.16.21255638; this version posted April 18, 2021. The copyright holder for this preprint (which was not certified by peer review) is the author/funder, who has granted medRxiv a license to display the preprint in perpetuity.

It is made available under a CC-BY-NC-ND 4.0 International license .

161 appears to peak in infected persons within the first week of infection (Cevik et al., 2020) and the

162 median incubation period for COVID-19 is estimated to be approximately five days (Lauer et al.,

$1632020)$.

164 Following a positive wastewater sample, clinical testing was performed on nearly all

165 residents living in the dorm via the TATS program (Betancourt et al., 2021). Individuals that

166 tested positive were removed from the dorm and transferred into isolation. However, some

167 individuals in the early stages of infection may have tested negative on the day of wastewater

168 testing, but tested positive after reaching peak viral load of SARS-CoV-2 a few days later. It is

169 possible that these individuals were shedding virus in feces even though they tested negative via

170 initial TATS conducted within 24 hours of a positive wastewater signal. Additionally, the full

171 dorm community was not always available on the first day of targeted testing and were tested a

172 day or more after a positive wastewater detection. Therefore, clinical data for 4-days following

173 positive wastewater samples was included in the count of infected individuals since these

174 persons likely shed and contributed virus to the wastewater samples for several days.

175 The majority (68 out of 81 ) of positive wastewater samples were associated with new

176 reported cases of infections within this 6-day period.

\section{2.5. Viral Shedding Rate Estimation}

178 The fecal shedding rate of SARS-CoV-2 RNA per gram of feces from an infected

179 individual was enumerated based on known concentrations of viral RNA in positive wastewater

180 samples and the fact that the total numbers of infected persons contributing to the total virus load

181 in the samples were also known. Equations from previous reports using viral loads in wastewater

182 to estimate the number of infected persons in a community (Ahmed et al., 2020; Chavarria-Miró

183 et al., 2021; Curtis et al., 2020) were modified so that the fecal shedding rate of viral RNA per 
medRxiv preprint doi: https://doi.org/10.1101/2021.04.16.21255638; this version posted April 18, 2021. The copyright holder for this preprint (which was not certified by peer review) is the author/funder, who has granted medRxiv a license to display the preprint in perpetuity.

It is made available under a CC-BY-NC-ND 4.0 International license .

184 infected person could be quantified. The fecal shedding rate (FS) in terms of genome copies per 185 gram-feces (gc/g-feces) was calculated as follows:

$$
F S=\frac{(V C * Q * f * h)}{G * I}
$$

where $\mathrm{VC}$ is the virus concentration (genome copies/L) in the wastewater sample, $Q$ is the flow rate $(\mathrm{gpm})$ of wastewater in the sewer manhole at time of sample collection, $f$ is the conversion factor between gallons and liters, $h$ is the conversion factor between minutes and days, $G$ is the typical mass of stool produced per person per day (Curtis et al., 2020; Rose et al., 2015), and $I$ is

191 total number of infected persons contributing to the wastewater sample based on the 6-day range

192 for clinical data (see Section 2.5). Confidence intervals were calculated based on the standard

193 deviations between sample calculations.

Fecal shedding rates based on N1 and N2 genes were calculated independently.

\subsection{Statistical Analysis}

Statistical analyses were performed in Microsoft Excel (version 16.47.1, 2021) and R

197 studio (R Studio Team (2020). RStudio: Integrated Development for R. RStudio, PBC, Boston,

198 MA. http://www.rstudio.com/). Multiple imputation for measurement error (MIME) was

199 performed to estimate flow rates for missing data when the flow probe was unavailable, as

200 previously described with modifications (Canales et al., 2018).

\section{3. Results}

\subsection{Asymptomatic and Symptomatic Clinical COVID-19 Cases}

Asymptomatic and symptomatic cases of COVID-19 were differentiated based on clinical

204 testing program - TATS for asymptomatic and CHS for symptomatic (see Section 2.4). For all

205 dates in the study period, a total of 711 clinical cases were reported among the 13 unique dorms.

206 Clinical data was combined for dorms with converged sewage systems (Dorm E-F and Dorm H- 
medRxiv preprint doi: https://doi.org/10.1101/2021.04.16.21255638; this version posted April 18, 2021. The copyright holder for this preprint (which was not certified by peer review) is the author/funder, who has granted medRxiv a license to display the preprint in perpetuity.

It is made available under a CC-BY-NC-ND 4.0 International license .

207 I). Across all dorms, 148 symptomatic cases and 563 asymptomatic cases were reported; thus,

$20879.2 \%$ of SARS-CoV-2 infections were asymptomatic and only $20.8 \%$ were symptomatic (Table

209 2).

210 Examining specific dorm communities, reported clinical cases ranged from zero in Dorm

211 L to 171 in Dorm D (Table 2). Dorms $\mathrm{G}$ and $\mathrm{M}$ had the fewest reported infections, as well as the

212 highest and lowest asymptomatic rates. With limited data (two infections in Dorm G and five

213 infections in Dorm M), the asymptomatic rate was calculated as $100 \%$ for Dorm G and $20 \%$ for

214 Dorm M. Combined Dorm E \& F was the only dorm to report equal number of symptomatic and

215 asymptomatic cases (Table 2). Seven of the eleven monitored communities had asymptomatic

216 rates between $70-85 \%$ (Table 2 ). Two dorms ( $\mathrm{E} \& \mathrm{~F}$ and $\mathrm{M}$ ) had asymptomatic rates at $50 \%$ or

217 below, while Dorm G was the only to report 100\% of new cases as asymptomatic (Table 2).

218 3.2. Virus Fecal Shedding Estimation

219 In total, 81 samples in the study period were positive for SARS-CoV-2 N1 and/or N2

220 gene(s) and 238 samples resulted in no detection of the virus (Table S3). Clinical and wastewater

221 data were aggregated (see Section 2.5) to calculate the N1 and N2 viral shedding rate per

222 infected person (see Section 2.6). Only 13 positive wastewater samples were omitted from viral

223 shedding calculations due to zero reported cases of infection within the 6-day range for clinical

224 data (Table S3). Negative wastewater samples were not included in viral shedding estimations

225 due to no detection of SARS-CoV-2 N1/N2 genes. Also, negative samples did not trigger a

226 response action to conduct clinical testing on residents; thus, there is limited clinical data for the

227 days that wastewater was negative. Overall, 68 total positive wastewater samples were aligned

228 with clinical data to extrapolate the fecal shedding rates of SARS-CoV-2 N1 and/or N2 genes. 
medRxiv preprint doi: https://doi.org/10.1101/2021.04.16.21255638; this version posted April 18, 2021. The copyright holder for this preprint (which was not certified by peer review) is the author/funder, who has granted medRxiv a license to display the preprint in perpetuity. It is made available under a CC-BY-NC-ND 4.0 International license .

The average $\mathrm{N} 1$ shedding rate per infected person was calculated to be $6.84 \pm 0.77 \log _{10}$ $230 \mathrm{gc} / \mathrm{g}$-feces, considering all positive wastewater samples $(\mathrm{n}=60)$ across all dorms (Table 3). The

231 median was $6.65 \log _{10} \mathrm{gc} / \mathrm{g}$-feces with a full range $5.74-9.76 \log _{10} \mathrm{gc} / \mathrm{g}$-feces (Table 3 ). Within

232 specific defined communities, Dorm C had the highest average N1 shedding rate at $7.26 \pm 0.14$

$233(\mathrm{n}=2)$, while Dorm A had the lowest average at $6.45 \pm 0.60 \log _{10}$ gc/g-feces $(\mathrm{n}=13)$. The widest

234 range of $\mathrm{N} 1$ shedding rates was found in Dorm $\mathrm{J}$ with a minimum at 5.98 and a maximum at 9.76

$235 \log _{10} \mathrm{gc} / \mathrm{g}$-feces.

The average $\mathrm{N} 2$ shedding rate per infected person was calculated to be $7.74 \pm 0.53 \log _{10}$ gc/g-feces across all positive wastewater samples $(n=32)$ from all dorms (Table 3$)$. The median was 7.60 with a full range from $6.74-8.60 \log _{10} \mathrm{gc} / \mathrm{g}$-feces (Table 3). For specific communities, 239 combined Dorm H \& I had the highest average N2 shedding rate at $8.21 \pm 0.55(\mathrm{n}=2)$, while

240 Dorm A had the lowest average at $7.21 \pm 0.35(n=5) \log _{10}$ gc/g-feces. The widest range of N2

241 shedding rates was found in Dorm $\mathrm{K}$ with a minimum at 7.32 and a maximum at $8.28 \log _{10} \mathrm{gc} / \mathrm{g}$ 242 feces.

With just one positive wastewater sample $(n=1)$ each, Dorms $C$ and D had the lowest

244 number of estimates for N2 viral shedding rates (Table 3). For Dorm D, the N1 shedding rate

245 could not be calculated due to zero wastewater samples being positive (i.e., non-detect) for the

246 N1 gene target (Table S3D). Although Dorm D (8.35 $\log _{10}$ gc/g-feces) reported a higher N2

247 shedding rate than Dorm H \& I (8.21 $\log _{10}$ gc/g-feces), it was not reported as a higher average 248 due to only a single sample $(\mathrm{n}=1)$. Combined Dorm E \& F also had a low number of samples 249 with positive detection for N1 $(n=2)$ and none for N2 (Table 3; Table S3E); thus, the shedding 250 rate for this combined dorm community could not be calculated for N2. 
medRxiv preprint doi: https://doi.org/10.1101/2021.04.16.21255638; this version posted April 18, 2021. The copyright holder for this preprint (which was not certified by peer review) is the author/funder, who has granted medRxiv a license to display the preprint in perpetuity. It is made available under a CC-BY-NC-ND 4.0 International license .

\section{Discussion}

\subsection{Estimation of Asymptomatic Cases as a Percent of Total Cases}

The total number of asymptomatic and symptomatic cases of COVID-19 were discerned

254 in this study based on clinical testing programs - TATS for asymptomatic and CHS for

255 symptomatic (see Section 2.4). Of the total 711 cases of COVID-19 that were reported via

256 positive antigen and/or PCR clinical tests, the vast majority (79.2\%) did not self-report and were

257 therefore considered asymptomatic. We should note that this finding may be overestimated in the 258 case that mildly symptomatic individuals did not self-report, which would categorize them as 259 asymptomatic if tested and found positive via TATS. This high rate of asymptomatic cases may

260 be due to the younger and perhaps healthier population surveyed in this study. However, the

261 finding suggests that the number of people infected with SARs-CoV-2 in the U.S. may be vastly

262 underestimated, which could have downstream effects for determining the immune population

263 and herd immunity thresholds.

\subsection{Viral Shedding Estimation}

Fecal shedding rates of SARS-CoV-2 RNA were estimated from dorm wastewater

266 samples using a modified equation from previous reports (Ahmed et al., 2020; Chavarria-Miró et

267 al., 2021; Curtis et al., 2020). This calculation accounts for the number of infected people within

268 a defined community, the amount of fecal material excreted, the shedding rate of infected

269 individuals, the flow rate of the wastewater, and the viral load within the wastewater. Of these

270 parameters, the fecal shedding rate of SARS-CoV-2 from infected individuals is the least known.

271 Until this research, shedding rate estimations were based upon limited results that indicated a

272 large variance across a small number of individuals (Wölfel et al., 2020). Shedding rates were

273 further extrapolated from the $90^{\text {th }}$ percentile of this limited dataset and used to calculate the 
medRxiv preprint doi: https://doi.org/10.1101/2021.04.16.21255638; this version posted April 18, 2021. The copyright holder for this preprint (which was not certified by peer review) is the author/funder, who has granted medRxiv a license to display the preprint in perpetuity.

It is made available under a CC-BY-NC-ND 4.0 International license .

274 number of infected persons contributing to viral loads in wastewater (Ahmed et al., 2020;

275 Chavarria-Miró et al., 2021; Curtis et al., 2020). However, models and predictions based on these

276 percentile shedding rates are likely to be inaccurate without pairing wastewater results with

277 clinical data.

278 In this current study, wastewater from student dorms with known defined communities

279 was sampled and assayed for SARS-CoV-2 RNA. Wastewater samples that tested positive for

280 viral RNA triggered targeted clinical testing of almost all residents within the specific dorm.

281 Consequently, fecal shedding rates could be calculated since virus wastewater concentrations and

282 the corresponding numbers of infected dorm residents were both known. These shedding rate

283 estimations are reasonable since each dorm was a theoretically closed population, where

284 nonresidents were prohibited from entering dorms, and individuals who were identified as

285 positive were isolated within other facilities. This also prevented recounting of positive

286 individuals and additional shedding on days subsequent to being counted as an infected

287 individual, since persistent shedding occurs over multiple days (Cevik et al., 2020; Gupta et al.,

288 2020). Therefore, the shedding rates calculated from the dorms represent incident infections

289 only.

For estimating the number of individuals shedding and contributing to the viral load in

291 wastewater samples, a 6-day range of clinical data was considered (See Section 2.5). Then, fecal

292 shedding rates of SARS-CoV-2 RNA were extrapolated from wastewater viral loads in samples

293 specific to UArizona dorms in which the exact number of infected persons was known. This

294 estimation is based on a calculation that accounts for the number of infected persons within a

295 defined community; the amount of fecal material excreted per person; the fecal shedding rate of 
medRxiv preprint doi: https://doi.org/10.1101/2021.04.16.21255638; this version posted April 18, 2021. The copyright holder for this preprint (which was not certified by peer review) is the author/funder, who has granted medRxiv a license to display the preprint in perpetuity. It is made available under a CC-BY-NC-ND 4.0 International license .

viral RNA from infected individuals; the flow rate of the wastewater and the viral load within the wastewater (See Section 2.6).

The aggregation of wastewater and clinical data enabled quantification of SARS-CoV-2

299 fecal shedding rates per infected person. Mean shedding rates averaged over all dorms with

300 positive wastewaters were $6.84 \pm 0.77 \log _{10}$ gc/g-feces based on the $\mathrm{N} 1$ gene and $7.74 \pm 0.53$

$301 \log 10 \mathrm{gc} / \mathrm{g}$-feces based on the N2 gene (Table 3). Statistical parameters included in Table 3

302 include number of samples (N), average values (Avg), standard deviation (Std dev), median

303 (Med), minimum (Min), and maximum (Max). These statistics are important to establish the 304 precision of the calculated shedding rates since many factors influence shedding rates. The

305 calculated rates based on the incidence of both N1 and N2 are fairly consistent with reasonable

306 calculated standard deviations. It is also important to note that mean rates are based on relatively

307 large numbers of calculations: $n=60(\mathrm{~N} 1)$ and $n=32(\mathrm{~N} 2)$. Notably, N2 gene values were

308 approximately $1-\log$ greater than the N1 gene in feces.

310 vary based on multiple factors such as sex, age, co-morbidities, socioeconomic status, and the

311 severity of symptoms and duration of infection. The duration of shedding appears to be affected

312 by the severity of the COVID-19 disease: asymptomatic (6 days) < mild symptoms (10 days) <

313 moderate symptoms (12 days) < serious (14 days) < critical (32 days) (Chen et al., 2020).

314 Recent reports also suggest that asymptomatic individuals had a shorter duration of viral

315 shedding than pre-symptomatic individuals (Hue et al., 2020).

316 Our data assumes early infection shedding rates because those people would be identified

317 within the 6-day period and removed from the dorm and brought into an isolated living quarter.

318 However, it is possible that some individuals may have started and/or continued shedding viral 
medRxiv preprint doi: https://doi.org/10.1101/2021.04.16.21255638; this version posted April 18, 2021. The copyright holder for this preprint (which was not certified by peer review) is the author/funder, who has granted medRxiv a license to display the preprint in perpetuity.

It is made available under a CC-BY-NC-ND 4.0 International license .

319 RNA in feces outside of the assumed 6-day period. The shedding rate may also be slightly

320 overestimated based on case capture definitions, as although the vast majority of individuals in

321 each dorm were tested after positive wastewater sample results, a minority of residents were not

322 tested. Shedding rates in this study are based on young university students who reside in

323 dormitories and do not necessarily approximate the general population. Nevertheless, a recent

324 study estimated the total number of active shedders from SARS-CoV-2 RNA levels in

325 wastewater from a large metropolitan area similarly demonstrating that shedding resulted from a

326 high proportion of asymptomatic individuals (Chavarria-Miró et al., 2021).

Some studies have reported similar initial shedding rates from symptomatic and

328 asymptomatic infections (Lavezzo et al., 2020; Van Vinh Chau et al., 2020); whereas, other

329 studies have found lower viral loads in asymptomatic cases (Han et al., 2020; Zhou et al., 2020).

330 Also, some reports indicate that only approximately 50\% of COVID-19 patients shed viral RNA

331 in stool samples (Gupta et al., 2020; Medema et al., 2020a), suggesting the possibility that not all

332 infected individuals shed viral RNA in feces. Regardless of these considerations, viral load in

333 wastewater in this study were based on all individuals (symptomatic and asymptomatic)

334 contributing to the sewage system. Therefore, fecal shedding estimates are general for defined

335 communities of mixed clinical cases, while considering the high proportion of asymptomatic to

336 symptomatic reported cases.

337 Lastly, it is important to note that no fecal samples were collected from individual

338 COVID-19 patients directly. Therefore, results in this study are specific to wastewater from

339 defined communities and is not intended to inform clinical data. Data and results from this study

340 should be compared with clinical research and evaluations.

3414.3 Concluding Remarks 
medRxiv preprint doi: https://doi.org/10.1101/2021.04.16.21255638; this version posted April 18, 2021. The copyright holder for this preprint (which was not certified by peer review) is the author/funder, who has granted medRxiv a license to display the preprint in perpetuity.

It is made available under a CC-BY-NC-ND 4.0 International license .

This study may have significant implications for public health. The fecal shedding rate of

343 SARS-CoV-2 RNA derived in this study can be utilized to estimate the total number of

344 infections in a community based on wastewater viral concentrations. Knowledge of disease

345 prevalence, especially as a leading indicator, can be used to assist communities in efficient

346 resource allocation to prevent and contain COVID-19 outbreaks. This study also provides further

347 understanding for the total number of cases that are symptomatic versus asymptomatic. Moving

348 forward, the number of reported cases can provide context for estimating the number of cases

349 that were asymptomatic and/or unreported. This, in turn, could have implications for

350 understanding the proportion of individuals that has been exposed to COVID-19 and for

351 understanding progress towards immunity within a community.

\section{Acknowledgements}

353 The authors thank the UArizona Task Force, Amy Glicken, and Jeff Bliznick for their

354 contributions. Financial support for the study was provided by the University of Arizona Campus

355 Re-Entry Task Force. The IRB at the University of Arizona reviewed the study and verified that

356 all data was de-identified and complied with the Human Subjects Protection. 
medRxiv preprint doi: https://doi.org/10.1101/2021.04.16.21255638; this version posted April 18, 2021. The copyright holder for this preprint

(which was not certified by peer review) is the author/funder, who has granted medRxiv a license to display the preprint in perpetuity.

It is made available under a CC-BY-NC-ND 4.0 International license .

\section{References}

Ahmed, W., Angel, N., Edson, J., Bibby, K., Bivins, A., O’Brien, J.W., Choi, P.M., Kitajima, M., Simpson, S.L., Li, J., Tscharke, B., Verhagen, R., Smith, W.J.M., Zaugg, J., Dierens, L., Hugenholtz, P., Thomas, K. V, Mueller, J.F., 2020. First confirmed detection of SARSCoV-2 in untreated wastewater in Australia: A proof of concept for the wastewater surveillance of COVID-19 in the community. Sci. Total Environ. 728, 138764. https://doi.org/10.1016/j.scitotenv.2020.138764

Akgiray, Ö., 2005. Explicit solutions of the Manning equation for partially filled circular pipes. Can. J. Civ. Eng. 32, 490-499. https://doi.org/10.1139/L05-001

Betancourt, W.Q., Schmitz, B.W., Innes, G.K., Prasek, S.M., Pogreba Brown, K.M., Stark, E.R., Foster, A.R., Sprissler, R.S., Harris, D.T., Sherchan, S.P., Gerba, C.P., Pepper, I.L., 2021. COVID-19 containment on a college campus via wastewater-based epidemiology, targeted clinical testing and an intervention. Sci. Total Environ. 779, 146408. https://doi.org/10.1016/j.scitotenv.2021.146408

Brönimann, S., Rebhan, K., Lemberger, U., Misrai, V., Shariat, S.F., Pradere, B., 2020. Secretion of severe acute respiratory syndrome coronavirus 2 in urine. Curr. Opin. Urol. 30, 735-739. https://doi.org/10.1097/MOU.0000000000000808

Canales, R.A., Wilson, A.M., Pearce-Walker, J.I., Verhougstraete, M.P., Reynolds, K.A., 2018. Methods for Handling Left-Censored Data in Quantitative Microbial Risk Assessment. Appl. Environ. Microbiol. 84. https://doi.org/10.1128/AEM.01203-18

Cevik, M., Tate, M., Lloyd, O., Maraolo, A.E., Schafers, J., Ho, A., 2020. SARS-CoV-2, SARS$\mathrm{CoV}$, and MERS-CoV viral load dynamics, duration of viral shedding, and infectiousness: a systematic review and meta-analysis. The Lancet Microbe. https://doi.org/10.1016/S26665247(20)30172-5

Chavarria-Miró, G., Anfruns-Estrada, E., Martínez-Velázquez, A., Vázquez-Portero, M., Guix, S., Paraira, M., Galofré, B., Sánchez, G., Pintó, R.M., Bosch, A., 2021. Time Evolution of Severe Acute Respiratory Syndrome Coronavirus 2 (SARS-CoV-2) in Wastewater during the First Pandemic Wave of COVID-19 in the Metropolitan Area of Barcelona, Spain. Appl. Environ. Microbiol. 87, e02750-20. https://doi.org/10.1128/AEM.02750-20

Curtis, K., Keeling, D., Yetka, K., Larson, A., Gonzalez, R., 2020. Wastewater SARS-CoV-2 Concentration and Loading Variability from Grab and 24-Hour Composite Samples. medRxiv 2020.07.10.20150607. https://doi.org/10.1101/2020.07.10.20150607

Gupta, S., Parker, J., Smits, S., Underwood, J., Dolwani, S., 2020. Persistent viral shedding of SARS-CoV-2 in faeces - a rapid review. Color. Dis. Off. J. Assoc. Coloproctology Gt. Britain Irel. 22, 611-620. https://doi.org/10.1111/codi.15138

Han, M.S., Seong, M.-W., Kim, N., Shin, S., Cho, S.I., Park, H., Kim, T.S., Park, S.S., Choi, E.H., 2020. Viral RNA Load in Mildly Symptomatic and Asymptomatic Children with COVID-19, Seoul, South Korea. Emerg. Infect. Dis.

https://doi.org/10.3201/eid2610.202449

Lauer, S.A., Grantz, K.H., Bi, Q., Jones, F.K., Zheng, Q., Meredith, H.R., Azman, A.S., Reich, N.G., Lessler, J., 2020. The Incubation Period of Coronavirus Disease 2019 (COVID-19) From Publicly Reported Confirmed Cases: Estimation and Application. Ann. Intern. Med. 172, 577-582. https://doi.org/10.7326/M20-0504 
medRxiv preprint doi: https://doi.org/10.1101/2021.04.16.21255638; this version posted April 18, 2021. The copyright holder for this preprint

(which was not certified by peer review) is the author/funder, who has granted medRxiv a license to display the preprint in perpetuity. It is made available under a CC-BY-NC-ND 4.0 International license .

Lavezzo, E., Franchin, E., Ciavarella, C., Cuomo-Dannenburg, G., Barzon, L., Del Vecchio, C., Rossi, L., Manganelli, R., Loregian, A., Navarin, N., Abate, D., Sciro, M., Merigliano, S., De Canale, E., Vanuzzo, M.C., Besutti, V., Saluzzo, F., Onelia, F., Pacenti, M., Parisi, S.G., Carretta, G., Donato, D., Flor, L., Cocchio, S., Masi, G., Sperduti, A., Cattarino, L., Salvador, R., Nicoletti, M., Caldart, F., Castelli, G., Nieddu, E., Labella, B., Fava, L., Drigo, M., Gaythorpe, K.A.M., Brazzale, A.R., Toppo, S., Trevisan, M., Baldo, V., Donnelly, C.A., Ferguson, N.M., Dorigatti, I., Crisanti, A., Ainslie, K.E.C., Baguelin, M., Bhatt, S., Boonyasiri, A., Boyd, O., Cattarino, L., Ciavarella, C., Coupland, H.L., Cucunubá, Z., Cuomo-Dannenburg, G., Djafaara, B.A., Donnelly, C.A., Dorigatti, I., van Elsland, S.L., FitzJohn, R., Flaxman, S., Gaythorpe, K.A.M., Green, W.D., Hallett, T., Hamlet, A., Haw, D., Imai, N., Jeffrey, B., Knock, E., Laydon, D.J., Mellan, T., Mishra, S., Nedjati-Gilani, G., Nouvellet, P., Okell, L.C., Parag, K. V, Riley, S., Thompson, H.A., Unwin, H.J.T., Verity, R., Vollmer, M.A.C., Walker, P.G.T., Walters, C.E., Wang, H., Wang, Y., Watson, O.J., Whittaker, C., Whittles, L.K., Xi, X., Ferguson, N.M., Team, I.C.C.-19 R., 2020. Suppression of a SARS-CoV-2 outbreak in the Italian municipality of Vo'. Nature 584, 425-429. https://doi.org/10.1038/s41586-020-2488-1

Medema, G., Been, F., Heijnen, L., Petterson, S., 2020a. Implementation of environmental surveillance for SARS-CoV-2 virus to support public health decisions: Opportunities and challenges. Curr. Opin. Environ. Sci. Heal. https://doi.org/10.1016/j.coesh.2020.09.006 Medema, G., Heijnen, L., Elsinga, G., Italiaander, R., Brouwer, A., 2020b. Presence of SARSCoronavirus-2 RNA in Sewage and Correlation with Reported COVID-19 Prevalence in the Early Stage of the Epidemic in the Netherlands. Environ. Sci. Technol. Lett. https://doi.org/10.1021/acs.estlett.0c00357

Morone, G., Palomba, A., Iosa, M., Caporaso, T., De Angelis, D., Venturiero, V., Savo, A., Coiro, P., Carbone, D., Gimigliano, F., Iolascon, G., Paolucci, S., 2020. Incidence and Persistence of Viral Shedding in COVID-19 Post-acute Patients With Negativized Pharyngeal Swab: A Systematic Review. Front. Med. 7, 562. https://doi.org/10.3389/fmed.2020.00562

Peccia, J., Zulli, A., Brackney, D.E., Grubaugh, N.D., Kaplan, E.H., Casanovas-Massana, A., Ko, A.I., Malik, A.A., Wang, D., Wang, M., Warren, J.L., Weinberger, D.M., Arnold, W., Omer, S.B., 2020. Measurement of SARS-CoV-2 RNA in wastewater tracks community infection dynamics. Nat. Biotechnol. 38, 1164-1167. https://doi.org/10.1038/s41587-0200684-Z

Rose, C., Parker, A., Jefferson, B., Cartmell, E., 2015. The Characterization of Feces and Urine: A Review of the Literature to Inform Advanced Treatment Technology. Crit. Rev. Environ. Sci. Technol. 45, 1827-1879. https://doi.org/10.1080/10643389.2014.1000761

Sun, J., Zhu, A., Li, H., Zheng, K., Zhuang, Z., Chen, Z., Shi, Y., Zhang, Z., Chen, S.-B., Liu, X., Dai, J., Li, X., Huang, S., Huang, X., Luo, L., Wen, L., Zhuo, J., Li, Y., Wang, Y., Zhang, L., Zhang, Y., Li, F., Feng, L., Chen, X., Zhong, N., Yang, Z., Huang, J., Zhao, J., Li, Y.-M., 2020. Isolation of infectious SARS-CoV-2 from urine of a COVID-19 patient. Emerg. Microbes Infect. https://doi.org/10.1080/22221751.2020.1760144

Van Vinh Chau, N., Lam, V.T., Dung, Nguyen Thanh, Yen, L.M., Minh, N.N.Q., Hung, L.M., Ngoc, N.M., Dung, Nguyen Tri, Man, D.N.H., Nguyet, L.A., Nhat, L.T.H., Nhu, L.N.T., Ny, N.T.H., Hong, N.T.T., Kestelyn, E., Dung, N.T.P., Xuan, T.C., Hien, T.T., Phong, N.T., Tu, T.N.H., Geskus, R.B., Thanh, T.T., Truong, N.T., Binh, N.T., Thuong, T.C., Thwaites, G., Van Tan, L., 2020. The Natural History and Transmission Potential of Asymptomatic 
medRxiv preprint doi: https://doi.org/10.1101/2021.04.16.21255638; this version posted April 18, 2021. The copyright holder for this preprint (which was not certified by peer review) is the author/funder, who has granted medRxiv a license to display the preprint in perpetuity. It is made available under a CC-BY-NC-ND 4.0 International license.

Severe Acute Respiratory Syndrome Coronavirus 2 Infection. Clin. Infect. Dis. an Off. Publ. Infect. Dis. Soc. Am. 71, 2679-2687. https://doi.org/10.1093/cid/ciaa711

Wang, W., Xu, Y., Gao, R., Lu, R., Han, K., Wu, G., Tan, W., 2020. Detection of SARS-CoV-2 in Different Types of Clinical Specimens. JAMA 323, 1843-1844. https://doi.org/10.1001/jama.2020.3786

Wölfel, R., Corman, V.M., Guggemos, W., Seilmaier, M., Zange, S., Müller, M.A., Niemeyer, D., Jones, T.C., Vollmar, P., Rothe, C., Hoelscher, M., Bleicker, T., Brünink, S., Schneider, J., Ehmann, R., Zwirglmaier, K., Drosten, C., Wendtner, C., 2020. Virological assessment of hospitalized patients with COVID-2019. Nature 581, 465-469. https://doi.org/10.1038/s41586-020-2196-X

Xiao, F., Sun, J., Xu, Y., Li, F., Huang, X., Li, H., Zhao, Jingxian, Huang, J., Zhao, Jincun, 2020. Infectious SARS-CoV-2 in Feces of Patient with Severe COVID-19. Emerg. Infect. Dis. 26, 1920-1922. https://doi.org/10.3201/eid2608.200681

Zhang, Y., Chen, C., Zhu, S., Shu, C., Wang, D., Song, J., Song, Y., Zhen, W., Feng, Z., Wu, G., $\mathrm{Xu}, \mathrm{J} ., \mathrm{Xu}, \mathrm{W} .$, n.d. Isolation of 2019-nCoV from a Stool Specimen of a LaboratoryConfirmed Case of the Coronavirus Disease 2019 (COVID-19). China CDC Wkly. 2, 123124. https://doi.org/10.46234/ccdcw2020.033

Zhou, R., Li, F., Chen, F., Liu, H., Zheng, J., Lei, C., Wu, X., 2020. Viral dynamics in asymptomatic patients with COVID-19. Int. J. Infect. Dis. 96, 288-290. https://doi.org/10.1016/j.ijid.2020.05.030 
Table 1: Meta-data for student dormitories.

\section{Fall 2020}

\begin{tabular}{crrll} 
Dorm & Occupancy $^{\mathbf{a}}$ & Capacity & Room Type & Bathrooms \\
\hline A & 611 & 722 & Single, Double & Community, All-Gender \\
B & 342 & 400 & Single, Double & Community \\
C & 123 & 181 & $\begin{array}{l}\text { Single, Double, Triple } \\
\text { b }\end{array}$ & Community \\
D & & & Single, Double, Suite- & \\
E & 623 & 731 & Style & Suite \\
F & 206 & 300 & Single, Double & Community, All-Gender \\
G & 56 & 60 & Single & Community \\
H & 231 & 300 & Apartments & In-Room (1 per bedroom) \\
I & 195 & 238 & Single, Double & Community, All-Gender \\
J & 181 & 238 & Single, Double & Community, All-Gender \\
K & 424 & 482 & Single, Double & Community \\
L & 328 & 369 & Double & Community, All-Gender \\
M & 76 & 106 & Single, Double, Triple & Community, Sink-in-Room \\
\hline
\end{tabular}

${ }^{a}$ Occupancy varied throughout the Fall 2020 semester, so the highest numbers of residents at any given time throughout the semester are shown.

${ }^{\mathrm{b}}$ Due to the pandemic, UArizona limited rooms to a maximum of two occupants. No tripleoccupant rooms were offered during the time of this analysis. 
Table 2: Clinical positives for COVID-19 in wastewater-monitored dorms, 8/17/20-11/20/20

\begin{tabular}{llllll}
\hline & $\begin{array}{l}\text { Clinical } \\
\text { Dorm }\end{array}$ & \multicolumn{2}{c}{ Symptomatic (CHS) } & \multicolumn{2}{c}{ Asymptomatic (TATS) $^{\mathbf{a}}$} \\
\cline { 3 - 6 } & Positives & Total & Percent $^{\mathbf{b}}$ & Total & Percent $^{\mathbf{b}}$ \\
\hline A & 164 & 35 & $21.3 \%$ & 129 & $78.7 \%$ \\
B & 92 & 16 & $17.4 \%$ & 76 & $82.6 \%$ \\
C & 10 & 3 & $30.0 \%$ & 7 & $70.0 \%$ \\
D & 171 & 34 & $19.9 \%$ & 137 & $80.1 \%$ \\
E \& F & 16 & 8 & $50.0 \%$ & 8 & $50.0 \%$ \\
G & 2 & 0 & $0.0 \%$ & 2 & $100.0 \%$ \\
H \& I & 74 & 17 & $23.0 \%$ & 57 & $77.0 \%$ \\
J & 111 & 16 & $14.4 \%$ & 95 & $85.6 \%$ \\
K & 66 & 15 & $22.7 \%$ & 51 & $77.3 \%$ \\
L & 0 & 0 & - & 0 & - \\
M & 5 & 4 & $80.0 \%$ & 1 & $20.0 \%$ \\
\hline Total & 711 & 148 & $20.8 \%$ & 563 & $79.2 \%$ \\
\hline a Asymptomatic cases may also include mildly symptomatic individuals that did not self-report. \\
b Percent of total new clinical positive cases of infection.
\end{tabular}


Table 3: SARS-CoV-2 Viral Shedding Per Infected Person Extrapolated from UArizona Dorm WBE

\begin{tabular}{|c|c|c|c|c|c|c|c|c|c|c|c|c|}
\hline \multirow[b]{2}{*}{ Dorm } & \multicolumn{6}{|l|}{ N1 } & \multicolumn{6}{|l|}{ N2 } \\
\hline & Avg. & Stdev & Med. & Min. & Max. & $\mathbf{n}$ & Avg. & Stdev & Med. & Min. & Max. & $\mathbf{n}$ \\
\hline A & 6.45 & 0.60 & 6.36 & 5.78 & 7.66 & 13 & 7.21 & 0.35 & 7.33 & 6.74 & 7.52 & 5 \\
\hline B & 6.99 & 0.49 & 7.21 & 6.21 & 7.40 & 5 & 7.51 & 0.33 & 7.51 & 7.27 & 7.74 & 2 \\
\hline $\mathrm{C}$ & 7.26 & 0.14 & 7.26 & 7.16 & 7.35 & 2 & 8.05 & - & - & - & - & 1 \\
\hline $\mathrm{D}^{\mathrm{a}}$ & - & - & - & - & - & - & 8.35 & - & - & - & - & 1 \\
\hline $\mathrm{E} \& \mathrm{~F}^{\mathrm{b}}$ & 6.65 & 0.12 & 6.65 & 6.57 & 6.73 & 2 & - & - & - & - & - & - \\
\hline$H \& I$ & 6.74 & 0.68 & 6.65 & 5.74 & 7.71 & 12 & 8.21 & 0.55 & 8.21 & 7.82 & 8.60 & 2 \\
\hline $\mathrm{J}$ & 6.99 & 0.96 & 6.78 & 5.98 & 9.76 & 14 & 7.43 & 0.29 & 7.54 & 7.01 & 7.93 & 10 \\
\hline K & 7.08 & 0.89 & 6.68 & 5.80 & 8.28 & 12 & 8.13 & 0.46 & 8.28 & 7.32 & 8.59 & 11 \\
\hline Total & 6.84 & 0.77 & 6.65 & 5.74 & 9.76 & 60 & 7.74 & 0.53 & 7.60 & 6.74 & 8.60 & 32 \\
\hline
\end{tabular}

All values are presented in $\log _{10}$ genome copies per gram of feces $\left(\log _{10}\right.$ gc/g-feces), except for $n$ (number of samples). Avg., average;

Stdev, standard deviation; Med., median; Min., minimum; Max., maximum; n, number of samples. (-), no data.

${ }^{\text {a }}$ N1 shedding rate could not be calculated from Dorm D due to no positive wastewater sample corroborating with a new reported case(s) of infection or clinical positive test.

${ }^{\mathrm{b}} \mathrm{N} 2$ shedding rate could not be calculated from Dorm E \& F due to no positive wastewater sample corroborating with a new reported case(s) of infection or clinical positive test. 